\title{
2006-1580: AN INVESTIGATION ON DESIGN EFFECTIVENESS AND EFFICIENCY OF TEAMS EQUIPPED WITH DESIGN INFORMATION SUPPORT TOOL (DIST)
}

\section{Gül Okudan, Pennsylvania State University}

Gül E. Okudan is an Assistant Professor of Engineering Design at The Pennsylvania State University. She received her Ph.D. from University of Missouri-Rolla. Her research interests include intelligent shop floor control, manufacturing strategy modeling and measurement, solid modeling, product design, and product design teams. Her published work appears in journals such as Journal of Engineering Design, Design Studies, Journal of Engineering Education, European Journal of Engineering Education and Technovation. She is a member of ASEE and ASME. She is also a National Research Council-US AFRL Summer Faculty Fellow of the Human Effectiveness Directorate for 2002, 2003 and 2004.

\section{Madara Ogot, Pennsylvania State University}

Madara Ogot is an Associate Professor in Engineering Design and Mechanical Engineering at The Pennsylvania State University. He is the co-author, along with Gül Okudan of an introductory engineering design text, Engineering Design: A Practical Guide. His current research interests include design under uncertainty, stochastic optimization and innovative design. He received his BSE from Princeton in 1987, and his MS and Ph.D. from the Pennsylvania State University in 1989 and 1991, respectively.

\section{Girish Rao, SPRINT}

Girish Rao has graduated from Penn State's Industrial and Manufacturing Engineering Department with M.S. in 2005. He is currently working as a development engineer for Sprint. 


\title{
An Investigation on Design Effectiveness and Efficiency of Teams Equipped with a Design Information Support Tool
} (Dist)

\begin{abstract}
In this work, it is hypothesized that by providing novice designers with a decision support tool (software), that can (i) take the designer's input, (ii) simplify design decision-making by automatically generating critical values in place of tedious hand calculations, and (iii) ensure consistency in integration of critical information, etc., designer error will be minimized as well as mental load and time demands on the designer reduced. This set of hypotheses is proven by way of studying the design outcomes of novice designers in a designed experiment.
\end{abstract}

The experiment is conducted in two stages: (1) conceptual design with no design information software, and (2) conceptual design with design information software. The first phase is used to document the potential designer errors as well as mental load and time demands when a design information software is not used. During the second phase, the performance of eight design teams equipped with the design information software is compared to that of a control group, which was not provided with the software. The results indicate a reduction in the number of information integration errors, the time needed for data analysis and the perceived workload of the designer. These results have implications for the engineering education classroom where design is an integral part of the curriculum.

\section{Introduction}

The design process is a complex information intensive activity requiring the designer to coordinate and integrate a large amount of information from different sources, formats, media and locations to arrive at a solution for a given design problem. With increasing globalization of products and services, engineering design firms have been forced to improve the productivity of their practices. To date, while advances in technology have been used in support of increasing productivity in latter stages of design (e.g., increased computing power in computer-aided design and engineering (CAD and CAE)), the efforts focusing on the initial stages have been limited ${ }^{1}$. Among the primary reasons are: (1) a lack of understanding of how design is done, and (2) an inadequate consideration of cognitive burdens due to the information rich design environment.

While there is consensus on a prescriptive definition of the design process, empirical studies of design have shown departures from the prescriptive process ${ }^{2}$. Further, currently available design systems have various drawbacks because they are developed without an understanding of the design process and hence they are limited in their effectiveness ${ }^{1}$. In addition, the designers of technological systems to support design activities do not adequately address the cognitive and human factors of their systems ${ }^{3}$. One of the important concerns regarding cognitive and human factors is the diversity of design information generated and utilized during the design process, which imposes considerable burden on the designer ${ }^{4}$.

These inhibiting factors for computer-based tool development in support of initial design stages, and their consequences, have several implications for design productivity. Among these are: 
a. A reduction in the designer's information awareness throughout the design process: As design requires integration of information in various formats from different sources at the right stage of design, consideration of all related information creates a mental load on the designer resulting in the potential omission of information, compromising the design outcome.

b. A reduction in the design team's collective awareness throughout the design process: when a number of designers are tasked to complete a design, information transfer among designers might also impact collective awareness in a team and hence the design outcome (e.g., a member not transferring the required information to others on time, or not transferring at all).

c. An increase in the errors in designer activities during the initial stages: While most design decision making tools such as Pugh charts or the Analytic Hierarchy Process (AHP), are intended to be easily applied even without computer support, under the pressures of designing to meet a deadline, they may become error prone.

Consequently, errors in these tools impact subsequent decisions during design.

In this paper, we hypothesize an improvement in the performance of designers when provided with a software tool to support information activities in the conceptual phases of design. Details of the experimental design used to verify the differences in design outcomes with and without the design support tool are provided in the following sections. The paper concludes with an analysis and discussion of the results.

\section{Experimental Design and Application}

The diversity of information generated and utilized during the design process places a considerable burden on the designer. Therefore, it is hypothesized that the use of a design information support tool can reduce the mental workload of the designer, increase performance by minimizing errors in transfer and integration of design information, and reduce the total time spent in design analysis activities.

A two stage experimental design approach is followed to test these hypotheses, as detailed in Figure 1. In the first stage, the design documentation of two groups of eight teams of novice designers completing preliminary design without a design information support tool (DIST) is analyzed to document the errors and performance of the design process. In addition, a post design survey was carried out to ascertain workload self-assessments of the designers, using the NASA-TLX ratings. The NASA TLX (task load index) rating system is a subjective workload assessment tool, where the user assigns ratings to six subscales: Mental Demands, Physical Demands, Temporal Demands, Performance, Effort and Frustration. NASA TLX has been found to be a sensitive and reliable measure of the subjective workload of the user ${ }^{5}$ and has been used in a wide variety of applications, including real and simulated flight tasks, air combat, vigilance tasks performance and in the use of remote control vehicles ${ }^{6}$. 




Figure 1. Experimental Design

In the second stage, the experimental group of eight design teams uses the DIST for the second design project. Their performance and workload ratings are compared with that of a control group of eight design teams, completing the same design problem, without access to the tool. The results of their performance and workload assessments are correlated with the usage logs from the DIST and the findings are presented.

\subsection{Stage I: Design Documentation of all Teams}

Data collection was completed using teams of an introductory required engineering design course at The Pennsylvania State University. ED\&G 100 is a project-based introduction to the engineering design process and relevant design techniques. Offered to first-year students, enrollment is capped at 32 students that are divided into eight teams of four members each. Teams in this course are formed randomly. Each week, the students have one session of class instruction, and two design lab and workshop sessions, each session being two hours in length. During the first seven weeks, the students are taught the generic design process and various design decision-making tools such as the Analytic Hierarchy Process, Morphological Charts and Pugh charts. The design lab and workshop sessions are intended for the students to focus on their design projects in a collaborative setting. The students are also instructed in the application of paper based and simple spreadsheet based tools, programmed in Microsoft ${ }^{\circledR}$ Excel. These are chiefly used to provide a basis to store the generated concepts and to provide basic computational assistance.

The design activities of the teams in two sections of this course were observed. The course is structured in the same way for both sections, and the performance of the eight design teams 
in each of the two sections were analyzed after the first design project. This analysis afforded an understanding of the performance and workload of the design teams during the first design project and also provided a baseline for the comparison in the second stage. Moreover, this was an analysis of design activities in actual practice, unlike laboratory experiments which might alter designer behavior and strategies.

During stage I, students were required to analyze the current offerings in the market and redesign an electric toothbrush that will better meet needs of the targeted population. They were expected to begin with a customer needs assessment, complete a literature search, product dissection and benchmarking, generate and select a viable concept, and end with detailed design specifications. The deliverables included a progress report four weeks into the project, and a final design document and presentation at the end of the seven week period.

The design documentations of the eight design teams were reviewed and evaluated by the course instructor. The performance of the eight design teams and their specific errors in the first design project are summarized in Table 1.

Table 1. Design Documentation Evaluations for the First Design Project

\begin{tabular}{|c|c|c|c|c|c|c|c|c|c|}
\hline Content & 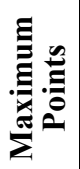 & $\underset{\Xi}{\Xi}$ & $\stackrel{N}{\Xi}$ & $\stackrel{\infty}{\Xi}$ & $\underset{\Xi}{\stackrel{\Xi}{\Xi}}$ & $\stackrel{n}{\Xi}$ & $\stackrel{\emptyset}{\Xi}$ & $\stackrel{\sim}{\Xi}$ & $\stackrel{\infty}{\Xi}$ \\
\hline $\begin{array}{l}\text { Abstract - Intro - Initial } \\
\text { Problem Statement }\end{array}$ & 5 & 3 & 5 & 5 & 5 & 4 & 5 & 5 & 5 \\
\hline $\begin{array}{l}\text { Customer Needs } \\
\text { Assessment }\end{array}$ & 10 & 8 & 8 & 10 & 10 & 10 & 8 & $\begin{array}{l}8 \\
P\end{array}$ & 10 \\
\hline $\begin{array}{c}\text { Revised Problem } \\
\text { Statement }\end{array}$ & 5 & 5 & 4 & 5 & 3 & 3 & 5 & 5 & 5 \\
\hline External Search & 10 & $\begin{array}{l}6 \\
S\end{array}$ & $\begin{array}{l}6 \\
S\end{array}$ & 9 & 10 & $\begin{array}{l}4 \\
\mathrm{~S}\end{array}$ & $\begin{array}{l}6 \\
S\end{array}$ & 8 & 10 \\
\hline Benchmarking & 10 & 8 & 8 & 10 & 10 & 8 & 9 & 7 & 8 \\
\hline Dissection & 10 & 8 & 8 & 9 & 9 & 2 & 9 & 8 & 9 \\
\hline Concept Generation & 10 & 5 & 9 & $\begin{array}{l}5 \\
\mathrm{~T}\end{array}$ & 9 & $\begin{array}{l}4 \\
\mathrm{~T}\end{array}$ & 9 & 8 & 10 \\
\hline Concept Selection & 10 & $\begin{array}{c}5 \\
\mathrm{~T}, \mathrm{M}\end{array}$ & 10 & $\begin{array}{l}8 \\
\mathrm{~T}\end{array}$ & $\begin{array}{l}8 \\
\mathrm{~T}\end{array}$ & $\begin{array}{l}9 \\
\mathrm{~T}\end{array}$ & $\begin{array}{c}6 \\
T, M\end{array}$ & $\begin{array}{c}5 \\
\mathrm{~T}, \mathrm{M}\end{array}$ & $\begin{array}{c}8 \\
\mathrm{M}\end{array}$ \\
\hline Final Design & 20 & 20 & 17 & 20 & 15 & 15 & $\begin{array}{l}20 \\
\mathrm{M}\end{array}$ & 13 & 20 \\
\hline Conclusion / Format & 10 & 10 & 7 & 9 & 10 & 10 & 10 & 9 & 10 \\
\hline Total & 100 & 78 & 82 & 90 & 89 & 68 & 87 & 76 & 95 \\
\hline
\end{tabular}

The errors in their design documentation, reflecting the errors in their design process, include: information integration errors, errors in application of design tools, insufficient search regarding external information sources, and errors in presentation of valid output from design tools (such as AHP, Morphological charts, etc.). An explanation of these errors, and the ways in which they were minimized with the DIST are presented below:

Information integration error $(\mathbf{M})$ : This indicates an omission in the transfer of information between design activities, which might include:

- criteria generated in customer needs assessment not being used in the selection of concepts,

- concepts generated via morphological charts not being used during concept selection, and

- solutions selected in concept selection not being used in the final design. 
The DIST minimizes this error by automatically transferring relevant information between design tools. For example, concepts generated in the morphological charts can be directly selected by the designer for use in the Pugh charts for concept evaluation.

Error in application of design tool (T): This indicates a computational error in the application of a design tool. For example, while comparing two solution concepts in a Pugh chart, the designer should use either $-1,0$ or +1 , to indicate an inferior, similar, or a superior concept, respectively. However, the design reports indicate that the designers compared alternatives with numbers beyond the appropriate range given above. The design tools embedded in DIST are designed to accept only valid input to prevent this error.

Insufficient external search (S): This indicates that the designer did not review all recommended design information resources. For example, the design brief includes relevant websites, books, patents and similar products from competing companies. Information that can be gathered from these sources might affect the quality of the final design. The DIST includes recommended information sources in the resources window and also allows the designer to enter comments for each information resource.

Incorrect presentation of design tool output $(\mathbf{P})$ : These errors are concerned with insufficient presentation of information in the design reports. For example, the criteria of the customer needs assessment are listed without their specific weights. The DIST provides a consistent output for each design tool in the interface, minimizing additional formatting activities by the designer.

\subsection{Assessment of Workload and Time Demands for Design Project-I}

The NASA TLX (task load index) rating system was included as part of a questionnaire, which was distributed to the designers after the first design project, along with questions about their familiarity with computing tasks and experience with engineering design projects. In the questionnaire, the user assigns ratings from one to five, corresponding to a workload of low to high, for each of the six subscales. All the six subscales were assumed to contribute equally to the overall workload.

The descriptive statistics for the NASA TLX workload measures are given in Table 2 for the experimental group and in Table 3 for the control group. The analysis indicates higher ratings for Effort and Temporal Demands for both groups compared to the other factors. This may be because this was the novice designers' first exposure to a collaborative project-based design course.

In addition to the NASA TLX workload assessment, the designers also indicated the approximate amounts of time spent on different phases of the design process. These phases were simply defined as gathering data (customer needs assessment, internal and external search), analyzing data (using AHP, Morphological and Pugh charts), and design report and presentation preparation. The user assigns ratings from one to four, corresponding to time durations of $<10 \%, 10-30 \%, 30-60 \%$ and $60-90 \%$ of the total duration of the project. The proportions of time spent in the different design activities are detailed in Table 4 for the experimental group, and in Table 5 for the control group. 
Table 2. Workload Assessments for the First Design Project (Experimental Group)

\begin{tabular}{|c|c|c|c|c|c|c|c|c|c|}
\hline Factors & 之导 & 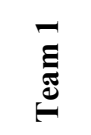 & 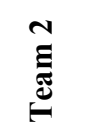 & $\stackrel{\infty}{\Xi}$ & $\underset{\Xi}{\Xi}$ & $\stackrel{n}{\Xi}$ & $\stackrel{0}{\Xi}$ & E & $\stackrel{\infty}{\Xi}$ \\
\hline Mental Demands & $\begin{array}{l}3.65 \\
0.97\end{array}$ & $\begin{array}{l}4.00 \\
0.81\end{array}$ & $\begin{array}{l}3.33 \\
0.57\end{array}$ & $\begin{array}{l}3.00 \\
0.00\end{array}$ & $\begin{array}{l}3.00 \\
1.00\end{array}$ & $\begin{array}{l}4.50 \\
0.70\end{array}$ & $\begin{array}{l}4.50 \\
0.70\end{array}$ & $\begin{array}{l}3.25 \\
1.50\end{array}$ & $\begin{array}{l}4.25 \\
0.95\end{array}$ \\
\hline Physical Demands & $\begin{array}{l}2.46 \\
1.06\end{array}$ & $\begin{array}{l}2.25 \\
0.50\end{array}$ & $\begin{array}{l}2.33 \\
0.57\end{array}$ & $\begin{array}{l}2.75 \\
0.50\end{array}$ & $\begin{array}{l}1.66 \\
0.57\end{array}$ & $\begin{array}{l}3.00 \\
0.00\end{array}$ & $\begin{array}{l}4.50 \\
0.70\end{array}$ & $\begin{array}{l}2.50 \\
1.29\end{array}$ & $\begin{array}{l}1.75 \\
1.50\end{array}$ \\
\hline $\begin{array}{l}\text { Temporal } \\
\text { Demands }\end{array}$ & $\begin{array}{l}4.03 \\
0.66\end{array}$ & $\begin{array}{l}4.25 \\
0.95\end{array}$ & $\begin{array}{l}3.66 \\
0.57\end{array}$ & $\begin{array}{l}3.75 \\
0.50\end{array}$ & $\begin{array}{l}4.33 \\
0.57\end{array}$ & $\begin{array}{l}4.00 \\
0.00\end{array}$ & $\begin{array}{l}4.00 \\
0.00\end{array}$ & $\begin{array}{l}4.50 \\
1.00\end{array}$ & $\begin{array}{l}3.75 \\
0.50\end{array}$ \\
\hline Performance & $\begin{array}{l}2.61 \\
1.20\end{array}$ & $\begin{array}{l}3.50 \\
1.00\end{array}$ & $\begin{array}{l}2.00 \\
0.00\end{array}$ & $\begin{array}{l}2.25 \\
0.95\end{array}$ & $\begin{array}{l}3.66 \\
1.52\end{array}$ & $\begin{array}{l}2.50 \\
0.70\end{array}$ & $\begin{array}{l}1.50 \\
0.70\end{array}$ & $\begin{array}{l}3.00 \\
1.41\end{array}$ & $\begin{array}{l}2.00 \\
1.41\end{array}$ \\
\hline Effort & $\begin{array}{l}4.26 \\
0.60\end{array}$ & $\begin{array}{l}3.75 \\
0.50\end{array}$ & $\begin{array}{l}4.00 \\
0.00\end{array}$ & $\begin{array}{l}4.00 \\
0.00\end{array}$ & $\begin{array}{l}4.33 \\
0.57\end{array}$ & $\begin{array}{l}4.50 \\
0.70\end{array}$ & $\begin{array}{l}5.00 \\
0.00\end{array}$ & $\begin{array}{l}4.25 \\
0.95\end{array}$ & $\begin{array}{l}4.75 \\
0.50\end{array}$ \\
\hline Frustration & $\begin{array}{l}3.23 \\
1.27\end{array}$ & $\begin{array}{l}3.50 \\
1.29\end{array}$ & $\begin{array}{l}3.00 \\
1.00\end{array}$ & $\begin{array}{l}2.50 \\
1.00\end{array}$ & $\begin{array}{l}3.00 \\
0.00\end{array}$ & $\begin{array}{l}3.00 \\
1.41\end{array}$ & $\begin{array}{l}5.00 \\
0.00\end{array}$ & $\begin{array}{l}4.00 \\
2.00\end{array}$ & $\begin{array}{l}2.50 \\
1.00\end{array}$ \\
\hline Overall Workload & $\begin{array}{c}17.57 \\
7.73\end{array}$ & $\begin{array}{c}21.25 \\
2.36\end{array}$ & $\begin{array}{c}18.33 \\
2.31\end{array}$ & $\begin{array}{c}18.25 \\
1.70\end{array}$ & $\begin{array}{l}15.00 \\
10.10\end{array}$ & $\begin{array}{l}14.33 \\
12.50\end{array}$ & $\begin{array}{l}12.25 \\
14.15\end{array}$ & $\begin{array}{l}21.5 \\
6.40\end{array}$ & $\begin{array}{c}19.00 \\
4.24\end{array}$ \\
\hline
\end{tabular}

(Means/Standard Deviations are on a scale of 5) (Overall Workload on a scale of 30)

\begin{tabular}{|c|c|c|c|c|c|c|c|c|c|}
\hline Factors & 之 & 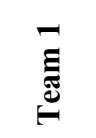 & $\stackrel{\sim}{\Xi}$ & $\stackrel{\oplus}{\Xi}$ & $\underset{\Xi}{\Xi}$ & $\stackrel{n}{\Xi}$ & $\stackrel{\bullet}{\Xi}$ & હ & $\stackrel{\infty}{\Xi}$ \\
\hline Mental Demands & $\begin{array}{l}3.24 \\
1.01\end{array}$ & $\begin{array}{l}3.75 \\
0.50\end{array}$ & $\begin{array}{l}2.75 \\
1.50\end{array}$ & $\begin{array}{l}2.50 \\
1.29\end{array}$ & $\begin{array}{l}3.67 \\
0.58\end{array}$ & $\begin{array}{c}4.00 \\
*\end{array}$ & $\begin{array}{l}2.67 \\
0.58\end{array}$ & $\begin{array}{l}4.00 \\
1.41\end{array}$ & $\begin{array}{l}3.50 \\
0.58\end{array}$ \\
\hline Physical Demands & $\begin{array}{l}2.20 \\
0.96\end{array}$ & $\begin{array}{l}2.75 \\
0.96\end{array}$ & $\begin{array}{l}1.25 \\
0.50\end{array}$ & $\begin{array}{l}1.75 \\
0.50\end{array}$ & $\begin{array}{l}3.00 \\
1.00\end{array}$ & $\begin{array}{c}4.00 \\
*\end{array}$ & $\begin{array}{l}2.00 \\
1.00\end{array}$ & $\begin{array}{l}1.50 \\
0.71\end{array}$ & $\begin{array}{l}2.50 \\
0.58\end{array}$ \\
\hline Temporal Demands & $\begin{array}{l}3.56 \\
0.92\end{array}$ & $\begin{array}{l}4.25 \\
0.96\end{array}$ & $\begin{array}{l}3.50 \\
1.00\end{array}$ & $\begin{array}{l}3.25 \\
1.26\end{array}$ & $\begin{array}{l}4.00 \\
1.00\end{array}$ & $\begin{array}{c}4.00 \\
*\end{array}$ & $\begin{array}{l}3.00 \\
1.00\end{array}$ & $\begin{array}{l}3.00 \\
0.00\end{array}$ & $\begin{array}{l}3.50 \\
0.58\end{array}$ \\
\hline Performance & $\begin{array}{l}2.48 \\
1.19\end{array}$ & $\begin{array}{l}2.25 \\
1.26\end{array}$ & $\begin{array}{l}2.25 \\
1.26\end{array}$ & $\begin{array}{l}2.00 \\
1.41\end{array}$ & $\begin{array}{l}3.33 \\
0.58\end{array}$ & $\begin{array}{c}2.00 \\
*\end{array}$ & $\begin{array}{l}2.33 \\
1.53\end{array}$ & $\begin{array}{l}1.50 \\
0.71\end{array}$ & $\begin{array}{l}3.50 \\
1.00\end{array}$ \\
\hline Effort & $\begin{array}{l}3.80 \\
0.65\end{array}$ & $\begin{array}{l}4.00 \\
0.82\end{array}$ & $\begin{array}{l}3.50 \\
0.58\end{array}$ & $\begin{array}{l}3.50 \\
1.29\end{array}$ & $\begin{array}{l}4.00 \\
0.00\end{array}$ & $\begin{array}{c}4.00 \\
*\end{array}$ & $\begin{array}{l}3.67 \\
0.58\end{array}$ & $\begin{array}{l}4.00 \\
0.00\end{array}$ & $\begin{array}{l}4.00 \\
0.00\end{array}$ \\
\hline Frustration & $\begin{array}{l}2.72 \\
1.06\end{array}$ & $\begin{array}{l}3.25 \\
0.96\end{array}$ & $\begin{array}{l}1.75 \\
0.96\end{array}$ & $\begin{array}{l}2.25 \\
0.96\end{array}$ & $\begin{array}{l}4.00 \\
0.00\end{array}$ & $\begin{array}{c}3.00 \\
*\end{array}$ & $\begin{array}{l}2.67 \\
1.53\end{array}$ & $\begin{array}{l}3.00 \\
1.41\end{array}$ & $\begin{array}{l}2.50 \\
0.58\end{array}$ \\
\hline Overall Workload & $\begin{array}{c}15.00 \\
7.68\end{array}$ & $\begin{array}{c}20.25 \\
3.59\end{array}$ & $\begin{array}{c}12.00 \\
7.62\end{array}$ & $\begin{array}{c}15.25 \\
2.99\end{array}$ & $\begin{array}{c}22.00 \\
2.00\end{array}$ & $\underset{*}{21.00}$ & $\begin{array}{c}12.25 \\
9.14\end{array}$ & $\begin{array}{c}11.33 \\
9.87\end{array}$ & $\begin{array}{c}19.50 \\
2.65\end{array}$ \\
\hline \multicolumn{10}{|c|}{$\begin{array}{l}\text { (Means/Standard Deviations are on a scale of 5) } \\
\text { (Overall Workload on a scale of } 30)\end{array}$} \\
\hline
\end{tabular}

In the first design project, the designers in the experimental group spent around $40 \%$ of their time in managing data (preparing reports and presentations), and around $30 \%$ in analyzing and gathering data. Similarly, the control group spent $40 \%$ of their time in managing data, $25 \%$ in gathering data and $35 \%$ in analyzing design data. 
Table 4. Time Allocations for Design Activities in the First Design Project

\begin{tabular}{|c|c|c|c|c|c|c|c|c|c|}
\hline Activity & ¿ & $\underset{\Xi}{\Xi}$ & $\stackrel{\text { N }}{\stackrel{\Xi}{\Xi}}$ & $\stackrel{\infty}{\Xi}$ & $\underset{\Xi}{\stackrel{\Xi}{\Xi \Xi}}$ & $\stackrel{n}{\Xi}$ & $\stackrel{\sigma}{\Xi}$ & $\stackrel{\sim}{\Xi}$ & $\stackrel{\infty}{\stackrel{\infty}{\Xi}}$ \\
\hline Gathering Data & $\begin{array}{l}2.07 \\
0.56\end{array}$ & $\begin{array}{l}1.75 \\
0.50\end{array}$ & $\begin{array}{l}2.33 \\
0.57\end{array}$ & $\begin{array}{l}2.25 \\
0.00\end{array}$ & $\begin{array}{l}3.00 \\
0.50\end{array}$ & $\begin{array}{l}2.00 \\
0.00\end{array}$ & $\begin{array}{l}2.00 \\
0.00\end{array}$ & $\begin{array}{l}1.50 \\
0.57\end{array}$ & $\begin{array}{l}2.00 \\
0.00\end{array}$ \\
\hline Analyzing Data & $\begin{array}{l}2.19 \\
0.69\end{array}$ & $\begin{array}{l}2.75 \\
0.50\end{array}$ & $\begin{array}{l}1.67 \\
0.57\end{array}$ & $\begin{array}{l}2.25 \\
0.50\end{array}$ & $\begin{array}{l}1.67 \\
1.15\end{array}$ & $\begin{array}{l}2.00 \\
0.00\end{array}$ & $\begin{array}{l}2.50 \\
0.70\end{array}$ & $\begin{array}{l}2.25 \\
0.95\end{array}$ & $\begin{array}{l}2.25 \\
0.50\end{array}$ \\
\hline Reports and presentations & $\begin{array}{l}2.92 \\
0.79\end{array}$ & $\begin{array}{l}2.75 \\
0.50\end{array}$ & $\begin{array}{l}3.00 \\
0.00\end{array}$ & $\begin{array}{l}3.50 \\
1.00\end{array}$ & $\begin{array}{l}1.67 \\
0.57\end{array}$ & $\begin{array}{l}2.50 \\
0.71\end{array}$ & $\begin{array}{l}2.50 \\
0.71\end{array}$ & $\begin{array}{l}3.25 \\
0.50\end{array}$ & $\begin{array}{l}3.50 \\
0.57\end{array}$ \\
\hline
\end{tabular}

(Means and Standard Deviations on a scale of four)

(Scale: $1:<10 \% ; 2: 10 \%-30 \% ; 3: 30 \%-60 \% ; 4:>60 \%$ )

\begin{tabular}{|c|c|c|c|c|c|c|c|c|c|}
\hline \multicolumn{10}{|c|}{$\begin{array}{l}\text { Table 5. Time Allocations for Design Activities in the First Design Project } \\
\text { (Control Group) }\end{array}$} \\
\hline Activity & $\sum \underset{\mathscr{E}}{\stackrel{\mathscr{\Xi}}{\Xi}}$ & $\underset{\Xi}{\Xi}$ & $\stackrel{N}{\Xi}$ & $\stackrel{\infty}{\Xi}$ & $\stackrel{+}{\Xi}$ & $\stackrel{n}{\Xi}$ & $\stackrel{\bullet}{\Xi}$ & 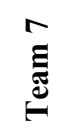 & $\stackrel{\infty}{\Xi}$ \\
\hline Gathering Data & $\begin{array}{l}1.92 \\
0.70\end{array}$ & $\begin{array}{l}2.00 \\
0.00\end{array}$ & $\begin{array}{l}2.25 \\
0.96\end{array}$ & $\begin{array}{l}1.50 \\
0.58\end{array}$ & $\begin{array}{l}2.00 \\
0.00\end{array}$ & $\begin{array}{c}2.00 \\
*\end{array}$ & $\begin{array}{l}2.00 \\
0.00\end{array}$ & $\begin{array}{l}1.00 \\
0.00\end{array}$ & $\begin{array}{l}2.25 \\
1.26\end{array}$ \\
\hline Analyzing Data & $\begin{array}{l}2.48 \\
0.71\end{array}$ & $\begin{array}{l}2.50 \\
0.58\end{array}$ & $\begin{array}{l}2.75 \\
0.96\end{array}$ & $\begin{array}{l}2.50 \\
0.58\end{array}$ & $\begin{array}{l}2.00 \\
1.00\end{array}$ & $\begin{array}{c}2.00 \\
*\end{array}$ & $\begin{array}{l}2.33 \\
0.58\end{array}$ & $\begin{array}{l}2.50 \\
0.71\end{array}$ & $\begin{array}{l}2.75 \\
0.96\end{array}$ \\
\hline Reports and presentations & $\begin{array}{l}2.84 \\
0.75\end{array}$ & $\begin{array}{l}3.00 \\
0.82\end{array}$ & $\begin{array}{l}2.25 \\
0.96\end{array}$ & $\begin{array}{l}2.75 \\
0.96\end{array}$ & $\begin{array}{l}3.00 \\
0.00\end{array}$ & $\begin{array}{c}3.00 \\
*\end{array}$ & $\begin{array}{l}3.00 \\
1.00\end{array}$ & $\begin{array}{l}3.00 \\
1.41\end{array}$ & $\begin{array}{l}3.00 \\
0.00\end{array}$ \\
\hline \multicolumn{10}{|c|}{$\begin{array}{c}\text { (Means and Standard Deviations on a scale of four) } \\
\text { (Scale: } 1:<10 \% ; 2: 10 \%-30 \% ; 3: 30 \%-60 \% ; 4:>60 \% \text { ) }\end{array}$} \\
\hline
\end{tabular}

At the end of the first stage, i.e. after the completion of the first design project by the control group and experimental group, the following measures were obtained:

- performance data from design documentation

- workload assessments for the first design project, and

- proportions of time spent in different design activities.

In the second phase, the experimental group is provided access to the DIST during their second design project. The above measures are collected after the completion of the second project and are analyzed to distinguish the effects of using DIST.

\subsection{Stage II: Use of DIST for the Second Project}

The second project is an industry sponsored design project where the students apply the design techniques learnt during the first session and build upon their experiences from the first design project. During the instructional sessions, the students are introduced to auxiliary design topics including TRIZ (Theory of Inventive Problem Solving), engineering ethics and green design. The second project is more intensive in terms of the project requirements and deliverables to be completed in the same duration of seven weeks.

In the second stage, the experimental group of eight teams was provided access to the DIST configured for the design problem. It was presented as a design support tool, and its usage was optional in the completion of the project. Each design team was provided a laptop loaded with the DIST, word processing, spreadsheet and Computer Aided Design (CAD) software. The teams were also rearranged (randomly) based on the peer reviews obtained after the first project. The performance and workload assessments of these teams are compared to that of a 
control group of eight teams, which carried out the same design problem, without access to the DIST.

As in the first design project, the documentation of the teams in the control group and the experimental group were evaluated by the same reviewer for the same levels of content. The performance of the experimental design teams is summarized in Table 6 and that of the control group, in Table 7.

A comparison of the design documentations of the experimental group between the first and the second design projects reveals a decrease in the total number of errors relating to information integration, the application of design tools and the presentation of their results. The reduction in the total points for the design documentation in the second project is attributed to the increased difficulty and workload of the second project.

Comparing the performance of the experimental group in the second design project with their performance in the first design project, it is seen that:

- There is a reduction in the number of errors made by the design teams in the second design project.

- The differences in temporal demands were found to be statistically significant ( $\mathrm{p}=$ 0.027). However, there is no significant difference in the time spent on analysis activities during the two design projects. This indicates that though the workload was greater in the second design project, the designers needed less time in analysis activities during the second project.

A comparison of the content of the second design project reports between the control and experimental group revealed some significant issues:

- The control group performed only a single Pugh chart analysis during concept selection, compared to the experimental group, which carried out one for each category of solution decomposition.

- Six out of the eight teams in the control group carried out a functional decomposition using morphological charts during concept generation. In contrast, the experimental group had a distribution of decompositions by function, user-actions and customer needs assessment. In addition, the functional decompositions of the six teams were very similar to each other in terms of the categories of decomposition. This indicates that the control group followed a more constrained design procedure.

- The control group was found to have fewer deliverables in terms of the number and detail of the working drawings.

These differences are attributed to the different instructional methods followed by the instructors for the two groups. However, this also indicates a much higher workload, amount of data analysis and detail of deliverables for the experimental group.

The performance comparison between the two groups was limited to the three stages in which DIST was applicable, namely Customer Needs Assessment (via the Analytic Hierarchy Process Tool), Concept Generation (via the Morphological Charts) and Concept Selection (via the Pugh Chars).

Comparing the performance of the two groups, in terms of number of errors, it is seen that the experimental group had fewer errors in these three sections. This is in spite of larger workloads, deliverables and analyses of data. The increased variability in the decompositions, 
alternatives and analyses of the experimental group has an effect on the quality of design due to a more rigorous design procedure being followed.

Table 6. Design Documentation Evaluations for the Second Design Project

\begin{tabular}{|c|c|c|c|c|c|c|c|c|c|}
\hline Content & 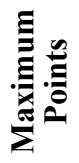 & Е &  & 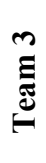 & 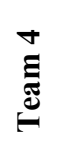 & $\stackrel{n}{\Xi}$ & ש &  & $\stackrel{\infty}{\Xi}$ \\
\hline $\begin{array}{c}\text { Abstract - Intro - Initial } \\
\text { Problem Statement }\end{array}$ & 5 & 3 & 3 & 5 & 4 & 3 & 4 & 3 & 4 \\
\hline Customer Needs Assessment & 10 & 7 & 8 & 9 & 10 & 6 & $\begin{array}{l}7 \\
\mathrm{M}\end{array}$ & 5 & 7 \\
\hline Revised Problem Statement & 5 & 5 & 4 & 4 & 4 & 3 & 5 & 5 & 5 \\
\hline External Search & 10 & 7 & 7 & 9 & 7 & 7 & 10 & 7 & 8 \\
\hline Benchmarking & 10 & 7 & 6 & 5 & 7 & 5 & 9 & 4 & 10 \\
\hline Concept Generation & 10 & 10 & 9 & 10 & 9 & $\begin{array}{c}8 \\
P, T\end{array}$ & 10 & 9 & 10 \\
\hline Concept Selection & 10 & $\begin{array}{l}8 \\
\mathrm{M}\end{array}$ & 10 & 10 & 9 & $\begin{array}{c}7 \\
\mathrm{M}, \mathrm{P}, \mathrm{T}\end{array}$ & 10 & $\begin{array}{l}7 \\
\mathrm{~T}\end{array}$ & 10 \\
\hline Final Design & 25 & 19 & 21 & 17 & 19 & 18 & 18 & 22 & 20 \\
\hline Calculations & 10 & 8 & 4 & 9 & 9 & 6 & 6 & 5 & 7 \\
\hline Conclusion / Format & 5 & 5 & 5 & 5 & 5 & 5 & 5 & 5 & 5 \\
\hline Total & 100 & 79 & 77 & 83 & 83 & 68 & 84 & 72 & 86 \\
\hline
\end{tabular}

Table 7. Design Documentation Evaluations for the Second Design Project

\begin{tabular}{|c|c|c|c|c|c|c|c|c|c|}
\hline \multicolumn{10}{|c|}{ (Control Group) } \\
\hline Content &  & $\underset{\Xi}{\Xi}$ & 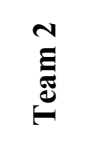 & $\stackrel{\overbrace{}}{\Xi}$ & $\underset{\mathscr{E}}{\stackrel{\Xi}{\Xi}}$ & $\stackrel{\text { n }}{\Xi}$ & 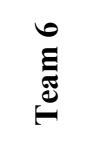 & 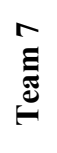 & $\stackrel{\infty}{\Xi}$ \\
\hline Customer Needs Assessment & 10 & $\begin{array}{l}6 \\
\mathrm{~T}\end{array}$ & 8 & $\begin{array}{c}7 \\
M\end{array}$ & $\begin{array}{c}5 \\
M\end{array}$ & $\begin{array}{l}7 \\
\mathrm{~T}\end{array}$ & $\begin{array}{c}7 \\
\mathrm{M}\end{array}$ & $\begin{array}{c}6 \\
M\end{array}$ & 7 \\
\hline Concept Generation & 10 & 9 & $\begin{array}{l}7 \\
\mathrm{~T}\end{array}$ & $\begin{array}{c}5 \\
M, T\end{array}$ & 9 & $\begin{array}{l}7 \\
\mathrm{P}\end{array}$ & $\begin{array}{c}6 \\
\text { M, T }\end{array}$ & 9 & 7 \\
\hline Concept Selection & 10 & $\begin{array}{c}8 \\
\mathrm{M}, \mathrm{T}\end{array}$ & ${ }^{7}, \mathrm{~T}$ & $\begin{array}{c}6 \\
M, T\end{array}$ & $\begin{array}{c}5 \\
M, T\end{array}$ & $\stackrel{5}{\mathrm{M}, \mathrm{T}}$ & $\begin{array}{c}5 \\
\text { M, T }\end{array}$ & $\begin{array}{l}8 \\
\mathrm{~T}\end{array}$ & $\begin{array}{l}8 \\
\mathrm{~T}\end{array}$ \\
\hline
\end{tabular}

\subsection{Assessment of Workload and Time Demands for Design Project-II}

The designers were given a survey questionnaire similar to the one used after the first design project. The summaries of the data obtained from the workload assessment survey are presented in Table 8 for the experimental group and in Table 9 for the control group. For the 
control group, the questionnaires returned were too few to categorize by teams, and therefore only the overall ratings are presented.

Comparing the assessments for the first and second design projects for the experimental group, the designers consistently rated five out of the six measures higher than the first design project, indicating the more intensive nature of the second project. The differences between the physical and temporal demands between the two projects were statistically significant with $p$ values of 0.00 and 0.027 respectively. This was due to the increased level of deliverables, as compared to the first project.

The tables also indicate an increase in the workloads between the experimental and the control group. For example, the control groups indicated a lower total workload for the first design project, but a higher workload for the second design project. In terms of raw data, the workload ratings for the experimental group increased by 3.7 points and for the control group increased by 8.8 points between the two design projects. Therefore, not only did the control group indicate higher workloads for the second design project, they also had higher increases in workload assessments between the first two design projects. These increased workloads are in spite of fewer deliverables as compared to the experimental group, and point to the advantage of the additional tool (DIST) provided.

The proportions of time spent in the different design activities are detailed in Table 10 for the experimental group, and in Table 11 for the control group. There was difference in the ratings for time spent in preparing reports and presentations between the first and the second projects for the experimental design group. The designers also reported a decrease in time spent gathering and analyzing data, which we attribute to the use of the DIST.

Table 8. Workload Assessments for the Second Design Project (Experimental Group)

\begin{tabular}{|c|c|c|c|c|c|c|c|c|c|}
\hline Factors & 之 & Е & $\stackrel{N}{\Xi}$ & $\stackrel{m}{\Xi}$ & $\stackrel{\nabla}{\Xi}$ & $\stackrel{n}{E}$ & ڤ્ & Ẽ & $\stackrel{\infty}{\Xi}$ \\
\hline Mental Demands & $\begin{array}{l}4.11 \\
0.75\end{array}$ & $\begin{array}{l}4.00 \\
0.00\end{array}$ & $\begin{array}{l}4.50 \\
0.57\end{array}$ & $\begin{array}{l}3.67 \\
1.15\end{array}$ & $\begin{array}{l}4.33 \\
0.57\end{array}$ & $\begin{array}{l}3.67 \\
0.57\end{array}$ & $\begin{array}{l}4.00 \\
0.81\end{array}$ & $\begin{array}{l}4.00 \\
1.00\end{array}$ & $\begin{array}{l}4.50 \\
1.00\end{array}$ \\
\hline Physical Demands & $\begin{array}{l}3.92 \\
0.99\end{array}$ & $\begin{array}{l}4.33 \\
0.57\end{array}$ & $\begin{array}{l}4.50 \\
0.57\end{array}$ & $\begin{array}{l}3.33 \\
1.53\end{array}$ & $\begin{array}{l}4.00 \\
1.00\end{array}$ & $\begin{array}{l}3.00 \\
1.00\end{array}$ & $\begin{array}{l}3.50 \\
1.29\end{array}$ & $\begin{array}{l}4.33 \\
0.57\end{array}$ & $\begin{array}{l}4.25 \\
0.95\end{array}$ \\
\hline Temporal Demands & $\begin{array}{l}4.48 \\
0.75\end{array}$ & $\begin{array}{l}5.00 \\
0.00\end{array}$ & $\begin{array}{l}5.00 \\
0.00\end{array}$ & $\begin{array}{l}4.33 \\
0.57\end{array}$ & $\begin{array}{l}4.00 \\
1.00\end{array}$ & $\begin{array}{l}4.00 \\
1.00\end{array}$ & $\begin{array}{l}4.25 \\
0.95\end{array}$ & $\begin{array}{l}4.33 \\
1.15\end{array}$ & $\begin{array}{l}4.75 \\
0.50\end{array}$ \\
\hline Performance & $\begin{array}{l}3.03 \\
1.28\end{array}$ & $\begin{array}{l}4.33 \\
0.57\end{array}$ & $\begin{array}{l}3.50 \\
1.29\end{array}$ & $\begin{array}{l}2.67 \\
2.08\end{array}$ & $\begin{array}{l}3.33 \\
1.15\end{array}$ & $\begin{array}{l}3.00 \\
0.00\end{array}$ & $\begin{array}{l}3.50 \\
1.00\end{array}$ & $\begin{array}{l}2.00 \\
1.73\end{array}$ & $\begin{array}{l}2.00 \\
0.81\end{array}$ \\
\hline Effort & $\begin{array}{l}4.25 \\
1.02\end{array}$ & $\begin{array}{l}4.67 \\
0.57\end{array}$ & $\begin{array}{l}4.50 \\
1.00\end{array}$ & $\begin{array}{l}5.00 \\
0.00\end{array}$ & $\begin{array}{l}4.33 \\
0.57\end{array}$ & $\begin{array}{l}3.33 \\
0.57\end{array}$ & $\begin{array}{l}4.00 \\
0.81\end{array}$ & $\begin{array}{l}3.00 \\
2.00\end{array}$ & $\begin{array}{l}5.00 \\
0.00\end{array}$ \\
\hline Frustration & $\begin{array}{l}3.77 \\
0.89\end{array}$ & $\begin{array}{l}4.33 \\
0.57\end{array}$ & $\begin{array}{l}4.00 \\
0.81\end{array}$ & $\begin{array}{l}3.66 \\
0.57\end{array}$ & $\begin{array}{l}4.00 \\
1.00\end{array}$ & $\begin{array}{l}3.00 \\
1.00\end{array}$ & $\begin{array}{l}3.25 \\
1.25\end{array}$ & $\begin{array}{l}3.66 \\
0.57\end{array}$ & $\begin{array}{l}4.25 \\
0.95\end{array}$ \\
\hline Overall & $\begin{array}{c}21.23 \\
7.98\end{array}$ & $\begin{array}{c}26.66 \\
1.15\end{array}$ & $\begin{array}{c}26.00 \\
2.94\end{array}$ & $\begin{array}{l}17.00 \\
12.19\end{array}$ & $\begin{array}{c}24.00 \\
2.65\end{array}$ & $\begin{array}{l}15.00 \\
10.42\end{array}$ & $\begin{array}{c}22.50 \\
4.65\end{array}$ & $\begin{array}{l}16.00 \\
10.80\end{array}$ & $\begin{array}{c}24.75 \\
2.63\end{array}$ \\
\hline
\end{tabular}

(Means and Standard Deviations on a scale of five)

(Overall Workload on a scale of 30 ) 
Table 9. Workload Assessments for the Second Design Project (Control Group)

\begin{tabular}{|c|c|c|c|c|c|c|c|}
\hline 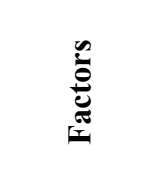 &  &  & 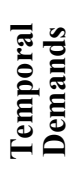 & 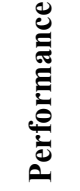 &  & : & $\begin{array}{l}\overline{\bar{\pi}} \\
\text { పे } \\
0\end{array}$ \\
\hline All Teams & $\begin{array}{l}4.50 \\
0.54\end{array}$ & $\begin{array}{l}3.38 \\
0.74\end{array}$ & $\begin{array}{l}4.50 \\
0.54\end{array}$ & $\begin{array}{l}3.38 \\
1.06\end{array}$ & $\begin{array}{l}4.75 \\
0.46\end{array}$ & $\begin{array}{l}3.31 \\
0.46\end{array}$ & $\begin{array}{c}23.81 \\
1.46\end{array}$ \\
\hline
\end{tabular}

(Means and Standard Deviations on a scale of five)

(Overall Workload on a scale of 30)

The experimental group indicated proportions of $25 \%, 28 \%$ and $47 \%$ in gathering, analyzing and managing data, while the control group indicated proportions of $24 \%, 33 \%$ and $43 \%$ respectively. This indicates that the control group identified a higher proportion of time spent in analyzing data as compared to the experimental group, despite having fewer deliverables in their final design documentation.

Table 10. Time Allocations for Design Activities in the Second Design Project (Experimental Group)

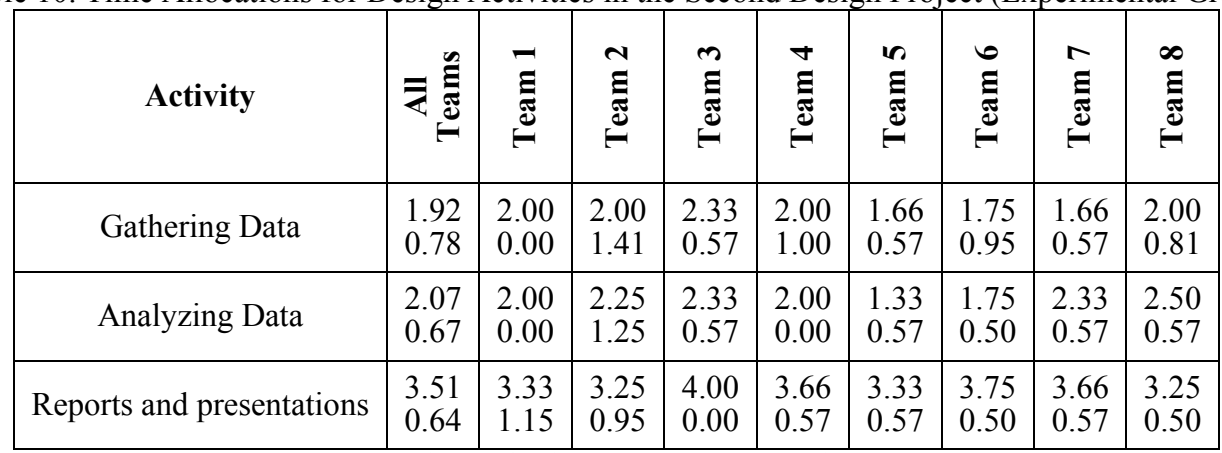

(Means and Standard Deviations on a scale of four)

(Scale: $1:<10 \% ; 2: 10 \%-30 \% ; 3: 30 \%-60 \% ; 4:>60 \%$ )

Table 11. Time Allocations for Design Activities in the Second Project (Control Group)

\begin{tabular}{|c|c|}
\hline Activity & All Teams \\
\hline \multirow{2}{*}{ Gathering Data } & 1.87 \\
& 0.35 \\
\hline \multirow{2}{*}{ Analyzing Data } & 2.50 \\
& 0.54 \\
\hline \multirow{2}{*}{ Reports and presentations } & 3.25 \\
& 0.88 \\
\hline
\end{tabular}

(Means and Standard Deviations on a scale of four)

(Scale: $1:<10 \% ; 2: 10 \%-30 \% ; 3: 30 \%-60 \% ; 4:>60 \%$ ) 


\subsection{DIST Usage}

The experimental group was also asked specific questions on their use of the software tool. Table 12 presents data regarding their assessment of the usefulness of different aspects of the interface. The features were rated on a scale of one to five, corresponding to "Not Useful" to "Very Useful". In addition, the software usage times were analyzed from the DIST logs for each design team. This usage (in hours: minutes: seconds), categorized by team and activity, is displayed in Table 13.

Table 12. DIST Feature Usefulness Rating

\begin{tabular}{|c|c|c|c|c|c|c|}
\hline \multirow{2}{*}{\multicolumn{2}{|c|}{ Features }} & \multicolumn{5}{|c|}{$\begin{array}{l}\text { Cumulative Usefulness } \\
\text { (High to Low) }\end{array}$} \\
\hline & & \multirow{2}{*}{$\begin{array}{c}\text {.000 } \\
17 \%\end{array}$} & \multirow{2}{*}{ 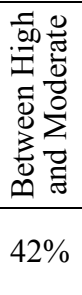 } & \multirow{2}{*}{  } & \multirow{2}{*}{ 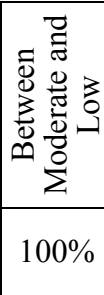 } & \multirow{2}{*}{\begin{tabular}{|c} 
3. \\
$100 \%$
\end{tabular}} \\
\hline a & $\begin{array}{l}\text { List of Design Process Tasks (Customer Needs } \\
\text { Assessment, Concept Generation etc.) }\end{array}$ & & & & & \\
\hline $\mathrm{b}$ & Analytical Hierarchy Process Tool & $25 \%$ & $50 \%$ & $96 \%$ & $100 \%$ & $100 \%$ \\
\hline $\mathrm{c}$ & Morphological Chart & $21 \%$ & $46 \%$ & $96 \%$ & $96 \%$ & $100 \%$ \\
\hline d & Pugh Charts & $29 \%$ & $54 \%$ & $79 \%$ & $92 \%$ & $100 \%$ \\
\hline $\mathrm{e}$ & Notes and Information Area & $22 \%$ & $39 \%$ & $78 \%$ & $100 \%$ & $100 \%$ \\
\hline $\mathrm{f}$ & $\begin{array}{l}\text { Design Information Resources (Design } \\
\text { Objective, Links etc.) }\end{array}$ & $17 \%$ & $26 \%$ & $87 \%$ & $100 \%$ & $100 \%$ \\
\hline $\mathrm{g}$ & Overall Design Interface & $9 \%$ & $52 \%$ & $87 \%$ & $100 \%$ & $100 \%$ \\
\hline
\end{tabular}

A majority $(>80 \%)$ of the participants found the design interface and design tools to be at least moderately useful, though they had some difficulties with the Pugh Chart tool.

Table 13. Interface Usage

\begin{tabular}{|c|c|c|c|c|c|}
\hline & $\begin{array}{c}\text { Analytic } \\
\text { Hierarchy } \\
\text { Process }\end{array}$ & $\begin{array}{c}\text { Morphological } \\
\text { Charts }\end{array}$ & $\begin{array}{c}\text { Pugh } \\
\text { Charts }\end{array}$ & $\begin{array}{c}\text { Total Tool } \\
\text { Usage }\end{array}$ & $\begin{array}{c}\text { Overall } \\
\text { Interface } \\
\text { Usage }\end{array}$ \\
\hline Team 1 & $1: 28: 45$ & $0: 18: 55$ & $0: 08: 23$ & $1: 56: 03$ & $2: 27: 18$ \\
\hline Team 2 & $0: 35: 32$ & $0: 07: 35$ & $2: 08: 50$ & $2: 51: 57$ & $4: 05: 52$ \\
\hline Team 3 & $0: 51: 27$ & $1: 08: 46$ & $3: 08: 59$ & $5: 09: 12$ & $9: 15: 32$ \\
\hline Team 4 & $0: 21: 00$ & $0: 19: 53$ & $1: 06: 30$ & $1: 47: 23$ & $3: 14: 54$ \\
\hline Team 5 & $0: 16: 30$ & $1: 11: 34$ & $1: 41: 31$ & $3: 09: 35$ & $5: 25: 16$ \\
\hline Team 6 & $1: 18: 51$ & $0: 34: 47$ & $0: 17: 15$ & $2: 10: 53$ & $3: 45: 51$ \\
\hline Team 7 & N.A. & N.A. & N.A. & N.A. & N.A. \\
\hline Team 8 & 0:22:41 & 0:14:25 & $2: 00: 37$ & $2: 37: 43$ & $3: 30: 33$ \\
\hline
\end{tabular}


The table indicates that the design teams spent a significant amount of time using the support tool. For design team seven, the interface was used on multiple computers and therefore the data obtained from the different design data files were found to be unreliable.

\section{Discussion and Analysis}

This research was motivated by the errors arising during design due to an omission in design information transfer between different design activities. By understanding the basis of these errors, and designing a design information support tool to minimize these errors, this research aimed to improve the quality and performance of the overall design process. Based on the comparison of two groups of design teams - the experimental group with access to the design information support tool, and the control group without access to the DIST, the following questions can be answered:

\section{a. Was DIST used by the design teams?}

The survey data reveals that 22 out of 30 designers indicated using the DIST. Since the DIST is being used collaboratively in a design team, different members can be expected to concentrate on different aspects of the project (creating the prototype, preparing the presentation, CAD drawings etc.) Therefore, a usage percentage of $73.33 \%$ indicates a high level of acceptance of the design interface, even though its usage was optional to the designer.

\section{b. How long was DIST used by the teams?}

The DIST logs indicate that the interface was used for a minimum of two and a half hours by every design team. In addition, the time spent on individual design tools is also reflected in the logs, as shown in Table 13.

\section{c. Did DIST usage make a difference on design performance?}

A reduction in the number of errors can be seen by comparing the performance of the experimental group between the first and second design projects (Table 1 and Table 6), despite an increase in workload and difficulty for the second design project. A comparison of the performance of the experimental and control groups in the second design project indicates a larger number of errors by the control group in spite of having fewer deliverables as compared to the experimental group.

In addition, the survey results reflect a decrease in time spent in data analysis activities from 2.19 to 2.07 from the first to the second design project (Table 4 and Table 10). Though this change is not statistically significant, it indicates that the designers did not spend much more time analyzing data in project 2 , even though it had more workload to be completed in the same duration as project 1 . Other experimental results based on the control group's performance include:

\section{a. How does the time vary between different design activities?}

The survey results indicated a higher proportion of time spent in design data analyses activities for the control group for the second project, while the experimental group indicated lower proportions of time as compared to the first design project and the control group results.

\section{b. How does the performance of the control group vary?}

The design documentation for the control group for the second design project reveals a larger number of errors during the design process, as compared to the experimental group. This is attributed to the usage of the design information support tool by the experimental group. 
Despite the above stated contributions however, the research work presented has limitations. One of the most important ones is that, while an adequate number of subjects were included in the software testing $(60,30$ in experimental group and 30 in the control group), all subjects were novice designers. Therefore, testing the impact of the design information support tool developed using a subject set of expert designers will be beneficial.

\section{Conclusions}

An evaluation of design outcomes completed using the design support tool indicated that:

1. Design teams, which used DIST, had fewer errors in their information analysis dense activities (e.g., customer needs assessment, concept selection) as compared to their previous design outcomes, even though the design project required more workload on their part.

2. The average time required reported for analyzing data is lower while using DIST, since the calculation and organization of data is managed by DIST, allowing the designer to perform better in similarly intensive activities.

3. The designers preferred to use DIST during their design activities, as opposed to other computer based tools, such as Microsoft ${ }^{\circledR}$ Excel.

4. Designers using DIST were able to complete their design activities with less perceived workload when compared to designers working on the same design problem, but without access to DIST.

These results clearly indicate the positive impact of a computer-based design information support tool on the design outcome performance, and related reduction of cognitive load on the designers. This positive impact stems from the fact that the dedicated software tool improves the awareness of the designer by integrating information from previous design activities, and reduces the potential for human error by incorporating automated design tools. These have direct effects on the productivity of the design process and the final design. Therefore, it is believed that these results will contribute to the much needed improvements in the collaborative design settings, particularly for the development of software tools.

\section{References}

1 SIM, S. K. \& DUFFY, A. H. B. (2004) Evolving A Model of Learning in Design. Research in Engineering Design, 15, 40-61.

2 GÜNTHER, J. \& EHRLENSPIEL, K. (1999) Comparing Designers from Practice And Designers with Systematic Design Education. Design Studies, 20, 439-451.

3 LANG, S. Y. T., DICKINSON, J. \& BUCHAL, R. O. (2002) Cognitive Factors In Distributed Design. Computers in Industry, 48, 89-98.

4 BAYA, V. (1996) Information Handling Behavior of Designers During Conceptual Design: Three Experiments. Palo Alto, Stanford University.

5 VITENSE, H. S., JACKO, J. A. \& EMERY, V. K. (2003) Multimodal Feedback: An Assessment of Performance and Mental Workload. Ergonomics, 46, 68-87.

6 RUBIO, S., DIAZ, E., MARTIN, J. \& PUENTE, J. M. (2004) Evaluation of Subjective Mental Workload: A Comparison of SWAT, NASA-TLX, and Workload Profile Methods. Applied Psychology-An International Review-Psychologie Appliquee-Revue Internationale, 53, 61-86. 